\title{
Critical Success Factors for ERP Systems Implementation in Public Administration
}

\author{
Ewa Ziemba \\ University of Economics, \\ Katowice, Poland
}

ewa.ziemba@ue.katowice.pl

\author{
Iwona Obłąk \\ Bytomska Spółka Informatyczna \\ COIG-4, Bytom, Poland
}

oblak.iwona@gmail.com

\begin{abstract}
The objective of our research was to explore the critical success factors for successful ERP systems implementation in public administration. First of all, the paper explains the nature of business process management, especially in public administration. Special attention is paid to ERP systems that are supporting business process management as well as critical success factors for their implementation are shown. Next, the case study of ERP systems implementation in the Polish government agency is described. Then, research findings concerning critical success factors for ERP systems implementation in public administration in Poland are shown. The results obtained from this research may prove to be helpful for researchers and scholars in developing studies on ERP systems supporting processes in public administration as well as government agencies interested in implementing ERP systems.
\end{abstract}

Keywords: business process, public administration, critical success factors, business process management, enterprise resources planning, ERP, BPM, CSF, government processes

\section{Introduction}

Looking for ways to increase efficiency, reduce costs, improve product quality, and increase customer satisfaction and shareholder value, organizations have realized that the source of success in this area lies in the performance of their processes. It turned out that it is not enough to look at an organization in terms of its functional structure, but also as a network of interrelated business processes. This led to the formulation of new management concepts, such as business process orientation (BPO) (Cieśliński, 2011; McCormack \& Johnson, 2001), process-based organizations (PO) (Hernaus, 2008; Levi, 2002; Seltsikas, 2001) and business process management (BPM) (Jeston \& Nelis, 2008; Lu, Sadiq, \& Governatori, 2009; Smith \& Finger, 2003; Trkman, 2010; Weske, 2007).

The process approach is based on an assumption that the optimization of an organization is fo-

Material published as part of this publication, either on-line or in print, is copyrighted by the Informing Science Institute. Permission to make digital or paper copy of part or all of these works for personal or classroom use is granted without fee provided that the copies are not made or distributed for profit or commercial advantage AND that copies 1) bear this notice in full and 2) give the full citation on the first page. It is permissible to abstract these works so long as credit is given. To copy in all other cases or to republish or to post on a server or to redistribute to lists requires specific permission and payment of a fee. Contact Publisher@InformingScience.org to request redistribution permission. cused on optimizing processes rather than optimizing functional units. As organizations move away from the process of grouping resources and expertise in hierarchical functional units, in order to move to the process level, a hierarchical structure of an organization is replaced by a horizontal processoriented structure, which foundations lie in the identified processes. The process organization is a set of mutually inter- 
woven processes that need to be effectively and efficiently managed (Smith \& Finger, 2003). Studies show that process management ensures more dynamic activities and allows for better use of resources (material, financial, and human) in the era of the economy based on knowledge, including knowledge resources (Han \& Park, 2009; Savvas \& Bassiliades 2009).

The process approach has already been used for a long time, but only in the production industry, and its aim was to enhance and improve the manufacturing processes (Hammer \& Champy, 1994; Jokiel, 2009). In contemporary organizations, a crucial role is not only played by the manufacturing processes but also by processes related to strategic management, communication with customers, cooperation with suppliers, workforce development, maintenance of machinery and equipment in motion, logistics, etc. (APQC, 2012).

Currently, the BPM principles and practices are used in public administration (Batko, 2011). This is due to the fact that government agencies as well as business organizations are evaluated in terms of competitiveness and attractiveness for the beneficiaries of their services. Every society and economy depends on the smooth and efficient operation of government agencies (Bhuiyan, 2011; Hwang \& Akdede, 2011; Pillania, 2011). The implementation of BPM in government agencies means the reconstruction and improvement of internal processes and administration processes related to the provision of government services for citizens, enterprises, and employees (Weerakkody, Janssen, \& Dwivedi, 2011). Its goal is to improve the efficiency and transparency of government services as well as increase in the participation of citizens and enterprises in the process of government decision making. Some researchers, due to the specific nature of government processes, introduce the concept of government process management (GPM) (Tregear \& Jenkins, 2007).

The application of a process approach and process management in organizations always requires the support of information systems (IS) and information technology (IT) (Taylor \& Williams, 1991). A key role is played here by Enterprise Resources Planning systems (ERP) (Umble, Haft, \& Umble, 2003). ERP systems incorporate best business practices and IT (Westrup \& Knight, 2000). Moreover, their implementation results in reducing cost and time cycle and in improving productivity, quality, and customer service benefits (Shang \& Seddon, 2002). ERP capability is expected to result in:

- business process efficiency (by reducing cost and time cycle, increasing productivity of the production process, and improving quality and customer service);

- effectiveness (by improving decision making and planning, and resource management and delivery); and

- flexibility (by building flexibility into IT infrastructure to reduce IT cost, by differentiating products and services, and by establishing and maintaining external linkages to customers and suppliers) (Karimi, Somers, \& Bhattacherjee, 2007).

The implementation of ERP systems is a complex technological, organizational, and business undertaking. It requires knowledge of a process approach, a specific organization of processes, its environment, competition, and IT. Business organizations already have significant experience in the implementation of ERP systems (Sammon \& Adam, 2010). However, the implementation of ERP systems in public administration requires cognitive and practical studies. There are major differences between business organization and public administration. Therefore, the same solutions, which are successfully used in business do not apply to public administration. Due to the nature of public administration, the good practices used in the implementation of ERP systems require verification and adjustment to their specific conditions. Most of the ERP systems are generally designed for private sector and do not meet specific public administration requirements. Bearing this in mind the critical success factors (CSFs) essential for the successful implementation of ERP systems are one of the researched spheres. CSFs are those areas and activities which 
should be primarily focused on in order to achieve the most satisfying results of the ERP systems implementation (Amid, Moalagh, \& Ravasan, 2012; Bueno \& Salmeron, 2008).

The objective of our research was to explore the critical success factors for successful ERP systems implementation in public administration. The paper explains the nature of business process management, especially in public administration. Special attention is paid to ERP systems supporting business process management, and critical success factors for ERP systems implementation are presented. Next, the case study of ERP systems implementation in the Polish government agency is described. Then, the research findings concerning critical success factors for ERP systems implementation in public administration by the example of Poland are shown. Finally, the discussion of the presented research findings is conducted and the directions for future work are suggested. In order to achieve the research goals, various scientific methods and techniques have been applied, such as a critical analysis of literature, case studies, an action research as well as methods of creative thinking and logical deduction.

We are confident that the results obtained from the research may prove to be helpful for researchers and scholars in developing studies on ERP systems supporting processes in public administration as well as government agencies interested in implementing ERP systems.

\section{Literature Review and Related Works - Process Management and ERP systems}

\section{Business Process Management}

Business process management is a stage of business orientation evolution (Weske, 2007). This evolution began with the first wave - continuous process improvement - passed through the second wave - business process reengineering - then the third wave - BPM (Smith, \& Fingar, 2003) - and finally achieved the fourth wave of business automation - process-based competition (Fingar, 2012). To get to the fourth wave, an organization must first make process excellence a sustainable asset. The third wave enables that asset, so this paper will concentrate on that. BPM is very closely related to other management concepts, such as change management and human resource management (Jeston \& Nelis, 2008; Lee, Kim, Seo, Kim \& Kim, 2011). Additionally, the management concepts of project management, quality management, and risk management (Jallow, Majeed, Vergidis, Tiwari, \& Roy, 2007; Trkman, 2010) have a strong impact on the BPM implementation.

BPM is a collection of concepts, methods, and techniques to support the administration, configuration, and analysis of business processes (Rudden, 2007; Smith \& Fingar, 2003; Weske, 2007; Zari, 1997). It is also defined that BPM is the management of cross organizational processes by gathering all sorts of methods, techniques, design tools, and analyses of operational business processes involving humans, organizations, IT, documents, and other sources of information (Aalst, Hofstede \& Weske, 2003). BPM might be perceived as organization's attempts of enhancing basic activities, i.e., manufacturing, marketing, communications, and other aspects of its operations (Trkman, 2010).

BPM has a specific lifecycle which consists of several steps that aim at improving the quality of business process in an incremental way (Debevoise, 2005). Usually, it is described in literature that BPM follows a life cycle that consists of three stages: process modeling, process execution, and process monitoring (Schumm, Leymann, \& Streule, 2010). Moreover, there is representation of BPM lifecycle in four stages: design (modeling), implementation, enactment, and analysis (Muehlen \& Rosemann, 2004). However, there is also wider understanding of the lifecycle: discovery and modeling of business process, validation and simulation, deployment and execution, 
monitoring and performance management, improving the process and starting everything from the beginning (Pourshahid, Amyot, Peyton, Ghanavati, Chen, Weiss, \& Forster, 2009).

To sum up, BPM is a collection of methods and techniques to manage stages of the BPM lifecycle involving humans, IT, data, and physical objects on the basis of business process. BPM allows organizations to automate and integrate internal and external business processes. Further, BPM enables an organization to optimize and increase the efficiency of processes, both those conducted by humans as well as fully automated.

The implementation of BPM requires perceiving an organization as a whole composed of many processes which determine its success. Additionally, it is necessary to apply information systems, ERP systems especially, that combine IT with BPM methodology (Winn \& Oo, 2011). This approach in the science of management and business practice is called Business Process Organization (BPO) (Cieśliński, 2011; McCormack, 2001; Škrinjar, Bosilj-Vukšic \& Indihar-Štemberger, 2008). Empirical studies have shown that BPO raises the overall performance of an organization, promotes innovation, and increases efficiency of employees (Škrinjar, Štemberger, \& Hernaus, 2007; Zaheer, Rehman, \& Khan, 2009).

\section{Government Process Management}

Contrary to business organizations, focused on their profitability and stakeholders' value, government agencies have the public interest at heart. Their success goes along with their reaching of social goals. Simultaneously, these agencies have to cope with social and political demands, which are not the regard of the private sector. To compound the problem, government agencies create policies or policy advice, which are more difficult to identify than the physical output or financial results of private sector organizations (Tregear \& Jenkins, 2007). The fundamental differences between business and government frameworks lead to occurrences in the public sector which bear the influence upon the attainment of effective, continuous process management.

Efficient public administration is one of the factors affecting the quality of life in a country; it plays an important role in the development of an economy as well as influences the evaluation of the economy by investors (Hezri \& Dovers, 2006). However, creating efficient administration is impeded by such factors (barriers) as (1) increasing bureaucracy (greater number of documents, statements, and reports), (2) complex and frequently changing administrative procedures, (3) inflation of law (the establishment of new laws and regulations by the legislators), (4) competition for financial resources (budget item justification, application for EU funds) (Batko, 2011; Hall, 2007). In order to overcome these barriers and become more competitive, public administration changes the management system from the functional model to the process oriented model. It faces the challenge of BPO implementation and what entails the implementation of BPM, change management, and project management (Sarantis, Charalabidis, \& Askounis, 2011; Young, Young, Jordan, \& O'Connor, 2012).

Public administration processes are more complex than in business organizations (Repa, 2006). This is due to the fact that public administration is a closely set organizational structure, where processes are formalized and decision-making is slow. This is compounded by the decisionmaking independence of individual departments of a government agency, which often pursue their own goals unrelated to the whole government agency. The process flow across departments is much more complex and depends on the task scope of individual employees. In addition, all government actions are hedged around with a great number of legal regulations. Those make the modification or improvement of processes not an easy task. They often require the introduction of changes in the law which is a lengthy process (Wilson, 1887).

Hence, in the context of public administration there is government process management (GPM) rather than business process management (Tregear \& Jenkins, 2007). GPM means the use of 
standard BPM principles and practices in public administration. Process management is fundamental to the development of an accountable, transparent, and responsive public administration.

Summing up, process management in public administration has a completely different character than in business organizations, where a process can be improved almost day by day (Schäfermeyer, Rosenkranz, \& Holten, 2012). This distinction comes from the public administration basics. Nevertheless, government agencies are aware of the key importance and necessity to improve government processes and the need to implement BPM (GPM).

In Poland, BPM is an often discussed and examined issue in the context of informationconditioning systems of public administration. This is reflected in current projects. One of them is the "E-government as a condition for development of Poland" (E-administracja warunkiem rozwoju Polski), the aim of which is to develop a reference model of public administration processes for city offices, regional offices and marshal's offices (official web site: http://www.uwm.edu.pl/eap ).

\section{ERP Systems in Government Processes Management}

Information systems and business processes are linked by the mutual relationship, the potential of which was defined, in the 90's, by Davenport and Short (1990). In Karim et al.'s (2007) opinion, information systems have a positive impact on the organization only when they comprehensively support business processes. Moreover, due to the high degree of complexity and interdependence of business processes, we are unable to manage them without the use of IS. Until recently, information systems could not support different stages of a BPM lifecycle, and business processes had to be adapted to the processes defined in the IS (Aalst et al., 2003). A few years ago, information systems were not able to cope with the dynamics, agility, and transparency of business processes. Currently, thanks to workflow engines (Smith \& Fingar, 2003) and web services technologies (Leymann, Roller, \& Schmidt, 2002; Moitra \& Ganesh, 2005) to support SOA architecture (Li, Muthusamy, \& Jacobsen, 2010; Specht, Drawehn, Thränert, \& Kühne, 2005), it is possible to manage processes occurring throughout the entire organization, not just within a single functional unit. ERP systems have significantly enhanced that as they integrate business processes and manage them (Davenport, 1998; Hammer \& Stanton, 1999; Robey, Ross, \& Boudreau, 2007). ERP systems enable management of business processes within functional units as well as those passing across the organization (Mabert, Soni, \& Venkataramanan, 2003). Furthermore, they integrate the flow of information within an organization (Cline \& Guynes, 2001) and manage and integrate physical, financial, and human resources of an organization (Kumar, Maheshwari, \& Kumar, 2002). As a result, ERP systems enable conducting business processes more efficiently and effectively and significantly affect business process improvement (Law \& Ngai, 2007; Wieder, Booth, Matolcsy, \& Ossimitz, 2006).

ERP systems implemented in public administration differ greatly from ERP systems for business. Due to the nature of processes and regulations, the functionality of ERP systems for public administration is different from its functionality for business organizations. ERP systems in public administration back up supporting processes rather than core processes (Becker, Kugeler, \& Rosemann, 2003; Porter, 1985), whose aim is to meet the collective and individual needs of citizens, resulting from the co-existence of people in communities (Kelly,1998). ERP systems in government agencies are mainly used to back up the supporting processes for accounting, human resource management, payroll management, inventory management, and fixed assets management. But even in this respect, ERP systems must be adapted to the requirements of public administration and, above all, to the applicable laws and standard procedures. This mostly concerns the law and procedures for accounting and budgetary accounting, employment, wages, and fixed assets management. In Poland, legal regulations and processes in this respect are different for 
public administration and business. Also, the management of inventory in a warehouse is based on a different principle than it is in manufacturing organizations.

In the literature and studies on ERP, systems for public administration are presented (Balzli \& Fragnière, 2012; Kumar, Maheshwari, \& Kumar, 2002; Raymond, Uwizeyemungu, \& Bergeron, 2006; Subramanian \& Peslak, 2012). In our opinion ERP systems dedicated to public administration should be considered as Government Resources Planning (GRP) systems. So far, the term GPR systems is not present in the literature. Also, this term is not used in the software market. Hence, in the further part of this paper the term ERP systems has been used.

\section{Critical Success Factors for ERP Systems}

ERP systems implementation is a complex exercise in technology innovation and organizational change management (Kumar et al., 2002; Markus \& Tanis, 2000) and it is not an easy task. It requires the coordination of many activities of an organization and a close cooperation of employees, managers, IT specialists, business analysts, consultants, and trading partners (Sambamurthy \& Kirsch, 2000). Furthermore, the ERP systems implementation differs from the traditional systems implementation in scale, complexity, organizational impact, user's participation, cost, and business impact (Grabski \& Leech, 2007). Additionally, there is a lack of proven scientific theories and experiences on the implementation of ERP systems in public administration.

These all create the need for research on the implementation of ERP systems in public administration. An important challenge is to identify the factors that determine the success of the implementation of ERP systems in public administration. CSFs are these areas and operations which should be focused on primarily in order to achieve the most satisfying results of the ERP systems implementation (Ziemba \& Papaj, 2012, 2013). We are confident that the theory of critical success factors gives good basis for stating what criteria should be followed during ERP systems implementation.

In the literature there are several definitions of critical success factors. Leidecker and Bruno have described CSFs as a set of characteristics, conditions and variables which should be adequately sustained, maintained, or managed in order to affect success factors of an organization competing in a specific industry (Leidecker \& Bruno, 1984). Rockart and Bullen (1981) have defined the critical success factors as the restricted number of fields in which positive outcome will result in "successful competitive performance" for an employee, organizational unit, and an organization as a whole. According to Ramaprasad and Williams, the CSFs should be used in three crucial areas including project management (63.49\%), information systems implementation $(49.21 \%)$, and requirements (47.62 \%) (Alaskari Ahmad, Dhafr, \& Pinedo-Cuenca, 2012; Ramaprasad \& Williams, 1998).

CSFs for information systems implementation, including the ERP systems, have been popularized by Rockart (1979). Since then, many researchers have defined the critical success factors that affect the implementation of ERP systems in business organizations (Alaskari et al., 2012; Law, Chen, \& Wu, 2010; Liu, 2011; Ngai, Law, \& Wat, 2008; Wang, Shih, Jiang, \& Klein, 2008). Table 1 summarizes the selected critical success factors for ERP systems implementation that are mentioned in the literature. The most extensive set of CSFs, broken down into three categories is presented by Hairul, Nasir, and Sahibuddin (2011). Critical analysis of those proposals has allowed us to identify the most important CSFs for ERP systems implementation. They include top management support and project management issues. Moreover, ERP systems implementation must be managed by experienced and well qualified project managers. Equally important are change management, business analysis, clear objectives, and effective communication between the project partners. 
Table 1: CSF for ERP systems implementation according to different authors

\begin{tabular}{|c|c|c|}
\hline $\begin{array}{l}\text { Somers and Nelson } \\
\text { (2001) } \\
22 \text { CSF's }\end{array}$ & $\begin{array}{c}\text { Hairul, Nasir, and Sahibuddin } \\
\text { (2011) } \\
\text { 26 CSF's }\end{array}$ & $\begin{array}{c}\text { Alaskari, Ahmad, Dhafr, and } \\
\text { Pinedo-Cuenca (2012) } \\
22 \text { CSF's }\end{array}$ \\
\hline $\begin{array}{l}\text { - Top management support } \\
\text { - Project champion } \\
\text { - User training and education } \\
\text { - Management of expectations } \\
\text { - Vendor/customer partnerships } \\
\text { - Use of vendors' development tools } \\
\text { - Careful selection of the appro- } \\
\text { priate package } \\
\text { - Project management } \\
\text { - Steering committee } \\
\text { - Use of consultants } \\
\text { - Minimal customization } \\
\text { - Data analysis and conversion } \\
\text { - Business process reengineering } \\
\text { - Defining the architecture } \\
\text { - Dedicated resources } \\
\text { - Project team competence } \\
\text { - Change management } \\
\text { - Clear goals and objectives } \\
\text { - Education on new business pro- } \\
\text { cesses } \\
\text { - Interdepartmental communica- } \\
\text { tion } \\
\text { - Interdepartmental co-operation } \\
\text { Ongoing vendor support }\end{array}$ & $\begin{array}{l}\text { People-related factors } \\
\text { - Effective project management } \\
\text { skills/methodologies (project man- } \\
\text { ager) } \\
\text { - Support from top management } \\
\text { - User/client involvement } \\
\text { - Skilled and sufficient staffs } \\
\text { - Good leadership } \\
\text { - Committed and motivated team } \\
\text { - Good performance by ven- } \\
\text { dors/contractors/ consultants } \\
\text { Process-related factors } \\
\text { - Clear requirements and specifica- } \\
\text { tions } \\
\text { - Clear objective/goal/scope } \\
\text { - Realistic schedule } \\
\text { - Effective communication and feed- } \\
\text { back } \\
\text { - Realistic budget } \\
\text { - Frozen requirement } \\
\text { - Proper planning } \\
\text { - Appropriate development process- } \\
\text { es/methodologies (process) } \\
\text { - Up-to-date progress reporting } \\
\text { - Effective monitoring and control } \\
\text { - Adequate resources } \\
\text { - Risk management } \\
\text { - Effective change and configuration } \\
\text { - Ganagement } \\
\text { - Good quality management } \\
\text { - } \text { - Elear assignment of roles and re- } \\
\text { Technical-user training provision } \\
\text { - Familiar with technolo- } \\
\text { - } \text { - Com/development methodology } \\
\text { structure }\end{array}$ & $\begin{array}{l}\text { - Top management support } \\
\text { - User training and education on } \\
\text { - } \text { oftware } \\
\text { - Business process reengineering } \\
\text { - Project management } \\
\text { - Effective communication } \\
\text { - Change culture } \\
\text { - Clear goals and objectives } \\
\text { - Use of consultants services } \\
\text { - Interdepartmental cooperation } \\
\text { - Upgrading infrastructure } \\
\text { - Financial resources } \\
\text { - Project team organization and } \\
\text { competence } \\
\text { - Legacy system management } \\
\text { - Change management } \\
\text { - Vendor support } \\
\text { - Project champion } \\
\text { - System technological } \\
\text { - ERP package selection } \\
\text { - Data accuracy } \\
\text { - Sponsorship } \\
\text { - Minimal customization } \\
\text { - Project manager }\end{array}$ \\
\hline
\end{tabular}

The literature lacks proven scientific theories and experiences referring to CSFs for ERP systems implementation in public administration. Hence, identifying CSFs for ERP systems implementation in public administration is becoming an important task.

\section{Research Methodology}

The goal of our research was to explore the critical success factors for successful ERP systems implementation in public administration. These are complex issues and they require research tasks of cognitive, methodological, and utilitarian characteristics. Such a spectrum of work involves adaptation of research methods to specific individual tasks and requires the use of different research tools, allowing for clarification and verification of results. 
In order to achieve the research goals, various scientific methods and techniques have been applied, such as a critical analysis of literature, action research, as well as methods of creative thinking and logical deduction.

To explain the nature of business process management, especially government process management, exploring ERP systems supporting business process management and identifying critical success factors for ERP systems implementation, a critical analysis of literature as well as methods of creative thinking and logical deduction have been used. In order to present the practical dimension of ERP systems implementation, especially CSFs for ERP systems implementation in public administration, action research has been applied. Action research as well as creative thinking and logical deduction helped to define critical success factors which are essential in case of managing ERP implementation in public administration.

The overall purposes of a literature review were to critically appraise and synthesize the current state of knowledge relating to the public administration, information systems, and the role of the business processes in the ERP system implementation. Action Research is characterized by an intensive communication between researchers and subjects. At all stages of ERP implementation one of the authors had a constant contact with project teams as a participant of the project. We used a lot of our practical experiences of information system implementation, ERP systems implementation in particular. We have been working as the IT project managers for many years. One of us works in an IT company on a regular basis. This company specializes in implementing ERP systems supporting processes in public administration.

The study on the ERP system implementation and its CSFs in public administration was conducted in 2010 and 2011. It concerned ERP system implementation in a big Polish government agency. This government agency consists of one central government unit and 21 local government units. The ERP system was composed of five modules: finance and accounting, human resource management, payroll management, inventory management, and fixed assets management. Semistructured interviews of the end users and the project team members were conducted, and shareable documentations related to ERP implementation were analyzed during the study. In addition, logical deduction has been used to propound CSFs.

\section{Research Findings - ERP System Implementation in Polish Government Agency}

The objectives of the researched government agency were to improve and automate government processes and to implement an integrated information system, i.e. an ERP system. There were many conditions for the ERP system implementation. First of all, the currently used information systems were not fully adapted to the needs of public administration; it did not meet new and emerging users' requirements and had difficulties in adapting to the changing laws. The system was technologically obsolete and, in terms of certain solutions, outdated. The individual modules of the system were not interconnected (integrated). Each process had to be started manually. The flow of information took a long time and it was impossible to perform a comprehensive analysis of the data. It was unfeasible to integrate information resources, which would allow meeting the analytical and reporting needs. This was due to the decentralized architecture of the system. In this architecture, each local government unit had its own system, in no way related to the system used in the central government unit. These all resulted in a significant prolongation of the decision-making process and a very negative effect on the efficiency and performance of the government agency.

Hence, the central government unit decided to implement an ERP system. The main objective of the implementation was the centralized management of the organizational structure of all government units and automation of supporting government processes for finance and accounting, 
human resources management, payroll management, inventory management, and fixed assets management. The expected result of the implementation was to eliminate unnecessary documentation, systemize document circulation, ensure a smooth flow of information, and make information accessible (which is relevant, timely to appropriate users. and in an appropriate form). The implementation work was undertaken by an IT company specializing in the development and implementation of ERP systems in public administration. This IT company submitted the lowest bid in response to a public procurement. A specifically set up project team of the central government unit was responsible for the implementation of the ERP system. The project team was composed of people from the departments of the central government unit, such as accounting, human resources, payroll, fixed assets, and inventory management, and from the IT department. And on the other hand, from the IT company the team was supported by business analysts, systems analysts, and project team leaders.

The aim of a project team should be to analyze and define the information requirements of ERP system users. The project team of the central government unit was required to analyze users' requirements and define them. The defined requirements had to be reflected in the functionality of the implemented ERP system and in government processes carried out in the system. The prospective users of the system from individual local government units were not at all involved in the process of creating requirements. This approach to studying requirements was a deliberate act aimed at structuring information requirements of the government processes as well as top-down imposition of a unified information model and uniform requirements of the process model for all government units. Until then, each local government unit conducted processes in their own way. This approach to defining information requirements resulted from the fact that the users knew about the planned implementation of the new system, however, showed much resistance to the coming changes. This was mainly due to the existing procedure habits, lack of understanding of the need for clarification in the ERP system, and the fear of change.

Another goal of the project team should be to analyze and develop a model of government processes. However, the government processes have not been defined. The project team assumed that it is sufficient to define the information requirements and that the ERP system already had the built-in procedures for implementing each process. This assumption was only partially correct. In fact, the ERP system had been equipped with the defined procedures for executing processes, but in some cases they differed from the actual needs of the government agency. It was also found that the government agency, on the one hand, expected that the ERP system would impose a certain procedure, and on the other hand, wanted to adapt the system to its individual requirements. An additional challenge was the fact that it was originally assumed that the processes would be implemented at two levels: national and local. During the project it became clear that the two levels intertwine with each other.

ERP system implementation always forces the introduction of changes in an organization. In our case there was a lack of change management, which should be the responsibility of a management team of a government agency. Neither were the employees of the government agency, who are the prospective users of an implemented, integrated ERP system, provided with the benefits that its application entails, nor with the challenges they would face and the tasks they would have to undertake. The implementation of an ERP system is always associated with an increased workload of users. Unfortunately, in this case they were not prepared beforehand that they would have to be actively involved in the implementation work, learn how to use the new system, and above all, to adapt to the changes introduced within the system. In the analyzed case, inadequate preparation for the upcoming changes, lack of additionally defined responsibilities, and lack of employees' motivation techniques resulted in reluctance to the implemented system.

The success of the implementation of the ERP system largely depends on the design team, its powers, and its management. Due to the broad scope of the project, the IT company providing the 
ERP system applied a proven methodology of project management. For the position of project manager a person with extensive professional experience in such projects was appointed. The government agency staff were competent people, but unfortunately employees of local government units were not involved in the design work. The success of the project not only depends on the competence of the members of the project team, but also on the communication within the team and on the line: government agency - IT company. In this case, the communication was clear and mutual. However, due to the formality burdened public administration, the design decision-making process was very long.

\section{Critical Success Factors for ERP System Implementation}

Our action research has become the basis for identifying the most important CSFs for the ERP system implementation in public administration. We have also used our experience in the field of ERP systems implementation. Those methods as well as the critical thinking and inductive reasoning led us to indicate the four groups of CSFs (Table 2):

- factors related to public procurement procedure;

- factors related to government processes management;

- factors related to project team competences (knowledge and skills of the project team related to implementation of information systems, especially ERP systems in public administration); and

- factors related to project management.

Table 2: CSFs for ERP systems implementation in public administration

\begin{tabular}{|c|c|c|c|}
\hline $\begin{array}{c}\text { Factors related to } \\
\text { public procurement } \\
\text { procedure } \\
\end{array}$ & $\begin{array}{c}\text { Factors related to } \\
\text { government processes } \\
\text { management }\end{array}$ & $\begin{array}{c}\text { Factors related to } \\
\text { project team compe- } \\
\text { tences } \\
\end{array}$ & $\begin{array}{c}\text { Factors related to } \\
\text { project management }\end{array}$ \\
\hline $\begin{array}{l}\text { - Clear and precisely } \\
\text { defined tender speci- } \\
\text { fication (information } \\
\text { and government pro- } \\
\text { cesses requirements, } \\
\text { technological re- } \\
\text { quirements, organiza- } \\
\text { tional requirements ) } \\
\text { - Realistic and chrono- } \\
\text { logically arranged } \\
\text { schedule } \\
\text { - Clear goals and ob- } \\
\text { jectives of the ERP } \\
\text { system implementa- } \\
\text { tion }\end{array}$ & $\begin{array}{l}\text { - Frozen information } \\
\text { requirements } \\
\text { - Identified govern- } \\
\text { ment processes } \\
\text { - Government pro- } \\
\text { cess reengineering }\end{array}$ & $\begin{array}{l}\text { - Project team compe- } \\
\text { tence on ERP systems } \\
\text { - Project team compe- } \\
\text { tence on public admin- } \\
\text { istration } \\
\text { - Use of consultants } \\
\text { - Cooperation with re- } \\
\text { search centers } \\
\text { - Expertise in IT }\end{array}$ & $\begin{array}{l}\text { - Top management support } \\
\text { - Clear assignment of roles } \\
\text { and responsibilities } \\
\text { - Change management } \\
\text { - Risk management } \\
\text { - Involvement ERP system } \\
\text { end-users } \\
\text { - Interdepartmental com- } \\
\text { munication } \\
\text { - Use of proven project } \\
\text { management methodolo- } \\
\text { gy } \\
\text { - Effective monitoring and } \\
\text { control }\end{array}$ \\
\hline
\end{tabular}

The listed CSFs for ERP systems in public administration implementation are similar to CSFs for ERP systems implementation in business organization. However, there are two new groups of factors. This means the factors related to public procurement procedures, which do not apply to business organizations and the factors related to government management processes, which are analogous to business organizations, but are different because of the specific nature of government processes. 


\section{Critical Factor Group One: Factors related to public procurement procedure}

Factors associated with the public procurement procedure are very important as they formally limit the range of functionality of an implemented ERP system. If the requirements are not defined, they are not a subject to the contract and, therefore, the IT company has no basis for their implementation. Moreover, it quite often happens that due to a lack of knowledge of ERP systems implementation very short and unrealistic deadlines for the system implementation are set. It may also be associated with a long-term procurement procedure, which aims to select the most advantageous offer. As a result, the initial date of the implementation is delayed in time, while the completion date of the implementation, which was provided for in the procurement, remains unchanged. Clear goals and objectives of the ERP system implementation are always specified in the announced public procurement and usually there are no ambiguities here. Nonetheless, they are included in this group of factors, since they largely determine the success of implementation.

\section{Critical Factor Group Two: Factors related to government processes management}

Regarded as the most important factors related to government management processes are frozen information requirements, identified government processes, and government process reengineering. Conducting the analysis of information requirements and government processes is an absolutely essential component of adopting the ERP system to the requirements of public administration. Government process reengineering is very often necessary in order to improve processes and increase their efficiency. Those all elements add up to the success of the ERP system implementation.

\section{Critical Factor Group Three: Factors related to project team competences}

The most important factors for ERP system implementation in public administration are related to project team competences. This refers to both the project team members, who are the employees of the IT company, as well as the government agency. Employees of the IT company should have experience and competence in implementing an ERP system in general, and especially in public administration. Moreover, government agency employees, who are a part of a design team, should have knowledge about government processes which will be supported by the ERP system and about information which it will provide. Their knowledge should cover the functional scope of the system. The government agency team should benefit from the knowledge of business analysis and information system implementation consultants. Support of research centers is also highly recommendable here.

\section{Critical Factor Group Four: Factors related to project management}

Factors related to project management, especially lack of top management support and clear assignment of roles and responsibilities may adversely affect the implementation. In addition, the use of proven project management methodology, especially for large projects, is essential. Without proper project management methodology there is a risk of system implementation failure. It is also important to use change management and risk management. ERP implementation brings many changes, which increase the risk of failure. Therefore, it is important to manage them properly. Also, end user involvement is not without significance. They will benefit from the implemented ERP system and should be involved in its implementation as soon as possible to be able to accept the changes. Also, the communication between team members and between end users from different departments has an impact on successful implementation. Effective monitor- 
ing and control should be used to coordinate the team's work as well as their possible collaboration with consultants and research centers.

To sum up, the obtained research results show that CSFs of ERP implementation in public administration in Poland can be classified into four groups: public procurement procedure, government business management, project team competences, and project management. These groups are analogous to the CSFs for ERP systems implementation demonstrated in the literature in general, but they have specific nature concerning public administration.

\section{Discussion}

We are of the view that CSFs scope for GPR is wider than in the case of ERP and includes four groups of factors, namely:

- factors related to public procurement procedure;

- factors related to government processes management;

- factors related to project team competences; and

- factors related to project management.

Particularly important are factors related to public procurement. Legal regulations in the public procurement procedure impose the order and GRP system purchase procedures and usually affect the prolongation of the purchase, but also the implementation time. The time between taking a decision about the need for the GRP system implementation and the actual beginning of implementation may take up to a year. The implementation is often completed one year after its launch. During this time, the system functionality requirements may change as a result of the so-called inflation of requirements or changes in the law regulations. Therefore, such an important factor in determining the success of the GRP system implementation is a straightforward and precisely defined tender specification, which simplifies and speeds up the public procurement process. Hence sufficiently long deadlines for the implementation in the event of prolonged tender should be provided. Thus, another CSF is creating a realistic and chronologically arranged schedule. It is also important to carry out a thorough analysis and to formulate a definition of government processes, without which, as it is known, it is difficult to adjust the GRP system to the specific needs of public administration.

The implementation of GRP systems is conducted as an IT project, and each project brings about changes. In the case of the GRP implementation in public administration, the scope of changes is quite extensive and mainly includes changes in government processes. In such cases, it is essential to apply the following management concepts: project management and change management that support, respectively, the completion of projects and the implementation of changes.

Public administration processes are more complex than in business organizations and very often their framework set by the law and statutory requirements. Therefore, BPM considered in the context of public administration requires a heavier workload, a bit different from BPM in the business context. Supporting business processes in public administration is associated with documents circulation and the GRP system that records changes made by these documents. Businessadministrative processes must be defined for the entire organization, not only for the actions of those supported by the GRP system. The knowledge of process management and administration is necessary here, as well as the knowledge of administrative law. Most of the processes are determined by the rules of law, which impose a specific flow of activities and their movement. They also limit, to a large extent, the possibility of modifying the business and administrative processes and their possible improvement. Management of such constructed processes imposes certain patterns that need to be mapped in the GRP system. Hence it is important to define the business pro- 
cesses and administrative systems correctly in the initial phase of the project, so they could be included in the proposed architecture of the GRP system.

The cooperation with external experts and research centers has a large impact on the successful implementation of the GRP system. Those experts using their knowledge and experience usually advise how to (1) improve the analysis and definition of requirements, (2) redesign processes, (3) involve future users in the work on defining the needs and streamlining processes, and (4) achieve greater benefits from the implementation of the GRP systems. This issue has been recognized by the Chancellery of the Prime Minister in Poland (Kancelaria Prezesa Rady Ministrów, 2011) as a result of a report on the decision-making processes in the public administration. It describes the problems associated with knowledge management in public administration: the lack of coordination in the acquisition of expertise and ordering studies. It also defines the need to introduce mechanisms on which a decision-making process can be based and to develop cooperation with external advisory and analytical centers. In this way, an acquired knowledge of external experts specializing in the implementation of the GRP systems has a significant impact on the success of the project.

Similar studies related to the CSFs for ERP systems implementation in public administration were carried out by Shah, Khan, Bokhari, and Raza (2011). They did not define CSFs for ERP implementation; however they have indicated barriers to successful ERP implementation in public administration in Pakistan. There are lack of user involvement, lack of top management support, lack of vendors' experience and support, and lack of change management. Not without significance was their identification of the role of social factors that are correlated with the barriers. As it might be noticed, those finding are similar to CSFs already defined in this paper. The importance of users' involvement and top management support has been defined as a CSF related to project management. Also vendors' experience and change management was pointed out as a CSF related to project team competences. Shah et al. put more emphasis on social factors; they mainly observed the lack of cooperation between the users of the implemented ERP system. This was also identified as one of the reasons for unsuccessful ERP implementation.

Other authors, who conducted research on ERP implementation in several public administration agencies in Canada, identified a number of critical management challenges such as training, upgrading infrastructure, project management, and stabilizing the ERP system (Kumar et al., 2002). They also pointed out that incompetent consultants and unskilled project persons were a major challenge in ERP system implementation. They found out that behavioral and management related challenges, rather than pure technical glitches such as software bugs and technical difficulties in configuration, were much more significant factors of trouble during ERP implementation. Those behavioral issues include the end user not being ready, resistance to change, lack of training, lack of coordination between functional groups, and lack of project planning. Comparing those finding with our research, the CSFs factors related to project management are similar to the defined above management challenges and the CSFs factors related to project team competences are similar to incompetent consultants and unskilled project persons. Moreover, the similarities mentioned in the other authors' studies do not point at business processes and public procurement procedure. Those two factors might be not significant in other researches cases, as there are cultural and legal differences between countries. To sum up other authors classified the barriers or critical challenges in a different way; however, the results of their research are similar to those presented in the paper.

\section{Conclusion}

Currently, government agencies as well as business organizations are increasingly adopting business process management. This makes it possible to increase the efficiency and effectiveness of government processes, resulting in a smooth and efficient operation of the society and the econ- 
omy. The BPM implementation is inextricably linked to the implementation of information systems, especially ERP systems. Due to the nature of public administration, the processes completed in it, and rules of law governing its functioning, the implementation of BPM and ERP systems in public administration differs from their introduction in business organizations.

In our opinion it is justified to use the terms (1) government process management instead of business process management and (2) government resources planning systems instead of enterprise resource planning systems. Moreover, research on GPM and GRP implementation as well as understanding and identifying the CSFs for their successful implementation is needed. It can be a valuable step towards enhancing chances of implementation because CSFs have a direct influence on GRP systems implementation. Lack of knowledge about the CSFs or their underestimation can contribute to the extended timing of the GRP systems implementation, failure of GRP systems functionality to the actual requirements of government agencies, or even the failure to implement the GRP.

Our paper makes an effort to make some contribution to the development of studies on CSFs for successful ERP systems implementation in public administration. It explores process management in public administration, investigates ERP systems implementation in a big government agency in Poland, and identifies a comprehensive set of CSFs by reviewing the literature and using the example of ERP systems implementation in this mentioned agency.

In our opinion, the implementation of ERP (GRP) systems in public administration poses a challenge and, thus, is an interesting subject of research. In view of the limitations of the literature on the BPM and GRP systems implementation in public administration, there is a need to focus future research efforts on their study. There is a need to conduct more in-depth research into the (1) approach to BPM implementation in public administration, (2) approach to GRP implementation in public administration, (3) "best practices" to be used to successfully manage ERP implementation, (4) CSFs for successful BPM and GRP implementation in public administration, and (5) analytical systems, especially Business Intelligence systems implementation in public administration. These will be considered as future work.

\section{Acknowledgement}

This paper has been supported by a grant entitled "Designing a system approach to sustainable development of the information society - on the example of Poland" from the National Science Centre in Poland, 2011/01/B/HS4/00974, 2011-2014.

\section{References}

Aalst, W. M. P., Hofstede, A. H. M. T., \& Weske, M. (2003). Business process management: A survey. Proceedings of the 2003 International Conference on Business Process Management, Springer-Verlag, Berlin 2003, 1-12. Retrieved November 25, 2012 from: http://bpt.hpi.unipotsdam.de/pub/Public/PaperArchive/bpm2003.pdf

Alaskari, O., Ahmad, M. M., Dhafr, N., \& Pinedo-Cuenca, R. (2012). Critical successful factors (CSFs) for successful implementation of lean tools and ERP systems. Proceedings of the World Congress on Engineering Vol III. WCE: London. Retrieved November 25, 2012 from: http://www.iaeng.org/publication/WCE2012/WCE2012_pp1627-1632.pdf

Amid, A., Moalagh, M., \& Ravasan, A. Z. (2012). Identification and classification of ERP critical failure factors in Iranian industries. Information Systems, 37, 227-237.

APQC. (2012). Process classification framework. Retrieved November 25, 2012 from: http://www.apqc.org/knowledgebase/download/268712/a\%3A1\%3A \%7Bi $\% 3 \mathrm{~A} 1 \% 3 \mathrm{Bi} \% 3 \mathrm{~A} 2 \% 3 \mathrm{~B} \% 7 \mathrm{D} /$ inline.pdf 
Balzli, C. E., \& Fragnière, E. (2012). How ERP systems are centralizing and standardizing the accounting function in public organizations for better and worse. In S. Chhabra \& M. Kumar (Eds.), Strategic enterprise resource planning models for e-government: Applications and methodologies (pp. 55-72). Hershey, PA: Information Science Reference. doi:10.4018/978-1-60960-863-7.ch004

Batko, R. (2011). Zarzadzanie zmiana w organizacjach publicznych [Change management in public administration]. Kraków: Wojewódzki Urząd Pracy.

Becker J., Kugeler. M., \& Rosemann, M. (2003). Process management: A guide for the design of business processes. New York: Springer.

Bhuiyan, S. H. (2011). Modernizing Bangladesh public administration through e-governance: Benefits and challenges. Government Information Quarterly, 28, 54-65.

Bueno, S., \& Salmeron, J. L. (2008). TAM-based success modeling in ERP. Interacting with Computers, 20,515-523.

Cieśliński, W. B. (2011). Doskonalenie procesowej orientacji przedsiębiorstw [Improving business process orientation]. Wrocław: University of Economic in Wrocław.

Cline, M. K., \& Guynes, C. S. (2001). A study of the impact of information technology investment on firm performance. The Journal of Computer Information Systems, 4(3), 15-19.

Davenport, T. H. (1998). Putting the enterprise into the enterprise system. Harvard Business Review, 76(4), $121-131$.

Davenport, T. H., \& Short, J. E. (1990). The new industrial engineering, information technology and business process redesign. Sloan Management Review, 4(31), 11-27.

Debevoise, T. (2005). Business process management with a business rules approach. Business knowledge architects. Virginia: BookSurge Publishing.

Fingar, P. (2012). Extreme competition. BPTrends. Retrieved November 25, 2012 from: http://www.bptrends.com/publicationfiles/10-02-2012-COL-ExtCompetition-Back-to-the-FutureFingar-pf.pdf

Grabski, S. V., \& Leech, S. A. (2007). Complementary controls and ERP implementation success. International Journal of Accounting Information Systems, 8, 17 - 39.

Hairul, M., Nasir, N., \& Sahibuddin, S. (2011). Critical success factors for software projects: A comparative study. Scientific Research and Essays, 10, 2174-2186. Retrieved November 24, 2012, from http://www.academicjournals.org/SRE

Hall, J. L. (2007). Implications of success and persistence for public sector performance. Public Organization Review, 7(3), 281-297. doi: 10.1007/s11115-007-0037-0

Hammer, M., \& Champy, J. (1994). Reengineering the corporation: A manifesto for business revolution. New York: Harper Business.

Hammer, M., \& Stanton, S. (1999). How process enterprises really work. Harvard Business Review, 77, 6, $108-118$.

Han, K. H., \& Park, J. W. (2009). Process-centered knowledge model and enterprise ontology for the development of knowledge management system. Expert Systems with Applications, 36, 7441-7447.

Hernaus, T. (2008). Process-based organization design model: Theoretical review and model conceptualization. Working Paper Series, 08-06.

Hezri, A. A., \& Dovers, S. R. (2006). Sustainability indicators, policy and governance: Issues for ecological economics. Ecological Economics, 60, 86-99.

Hwang, J., \& Akdede, S. H. (2011). The influence of governance on public sector efficiency: A crosscountry analysis. The Social Science Journal, 48, 735-738.

Jallow, A. K., Majeed, B., Vergidis, K., Tiwari, A., \& Roy, R. (2007). Operational risk analysis in business processes. BT Technology Journal, 25(1), 168-177. 
Jeston, J., \& Nelis, J. (2008). Business process management, practical guidelines to successful implementation (2nd ed.). Oxford: Elsevier.

Jokiel, G. (2009). Podejście procesowe w zarządzaniu - geneza i kierunki rozwoju koncepcji [Process approach to management - The genesis and direction of development of the concept]. In S. Nowosielski, Podejście procesowe w organizacjach [Business process approach] (pp. 15-22). Wrocław: University of Economic in Wrocław.

Kancelaria Prezesa Rady Ministrów. (2011). Podniesienie jakości procesów decyzyjnych w administracji rzadowej poprzez wykorzystanie potencjatu środowisk naukowych i eksperckich [Improving the quality of decision-making processes of government through the use of the potential of scientific and expert]. Warszawa: Kancelaria Prezesa Rady Ministrów.

Karim, J., Somers, T. M., \& Bhattacherjee, A. (2007). The impact of ERP implementation on business process outcomes: A factor-based study. Journal of Management Information Systems, 24(1), 101-134.

Kelly, R. M. (1998). An inclusive democratic politcy, representative bureaucracies, and the new public management. Public Administration Review, 8, 201.

Kumar, V., Maheshwari, B., \& Kumar, U. (2002). ERP systems implementation: Best practices in Canadian government organizations, Government Information Quarterly, 19, 147-172.

Law, C. C. H., \& Ngai, E. W. T. (2007). ERP systems adoption: An exploratory study of the organizational factors and impacts of ERP success. Information \& Management, 44, 418-432.

Law, C. C. H., Chen, C. C., \& Wu, B. J. P. (2010). Managing the full ERP life-cycle: Considerations of maintenance and support requirements and IT governance practice as integral elements of the formula for successful ERP adoption. Computers in Industry, 61, 297-308.

Lee, J., Kim, H., Seo, W., Kim, K., \& Kim, C. H. (2011). Condition-based process patterns for modeling of human processes in knowledge-intensive business Services. Expert Systems with Applications, 38, 4025-4038.

Leidecker, J. K., \& Bruno, A. V. (1984). Identifying and using critical success factors. Long Range Planning, 17, 23-32.

Levi, M. H. (2002). The business process (quiet) revolution: Transformation to process organization, interfacing technologies corporation. In K. Kosanke, R. Jochem, J. G. Nell, \& A. O. Bas (Eds.), Enterprise inter- and intra- organizational integration (pp. 147-157). Berlin: Springer.

Leymann, F., Roller, D., \& Schmidt, M. T. (2002). Web services and business process management. IBM Systems Journal, 41(2), 198-211.

Li, G., Muthusamy, V., \& Jacobsen, H. A. (2010). A distributed service oriented architecture for business process execution. ACM Transactions on Web, 4(2).

Liu, P. L. (2011). Empirical study on influence of critical success factors on ERP knowledge management on management performance in high-tech industries in Taiwan. Expert Systems with Applications, 38, 10696-10704.

Lu, R., Sadiq, S., \& Governatori, G. (2009). On managing business processes variants. Data and Knowledge Engineering, 68, 642-664.

Mabert, V., Soni, A,. \& Venkataramanan, M. A. (2003). Enterprise resource planning: managing the implementation process. European Journal of Operational Research, 146(2), 302-314.

Markus, M. L. \& Tanis, C. (2000). The enterprise systems experience - From adoption to success. In R. W. Zmud (Ed.), Framing the domains of IT management: Projecting the future through the past (pp.173207). Cincinnati: Pinnaflex Publishing.

McCormack, K. (2001). Business process orientation: Do you have it? Quality Progress, 34(1), 51.

McCormack, K. P., \& Johnson, W. C. (2001). Business process orientation. Gaining the e-business competitive advantage. Florida: St. Lucie Press.

Moitra, D., \& Ganesh, J. (2005). Web services and flexible business processes: Towards the adaptive enterprise. Information \& Management, 42(7), 921-933. 
Muehlen, M. Z., \& Rosemann, M. (2004). Multi-paradigm process management, Workshops - 5th Workshop on Business Process Modeling, Development and Support, pp. 169-175. Retrieved November 25, 2012 from: http://pdf.aminer.org/000/074/466/multi_paradigm_process_management.pdf

Ngai, E. W. T., Law, C. C. H., \& Wat, F. K. T. (2008). Examining the critical success factors in the adoption of enterprise resource planning. Computers in Industry, 59, 548-564.

Pillania, R. K. (2011). The state of research on technological uncertainties, social uncertainties and emerging markets: A multidisciplinary literature review. Technological Forecasting \& Social Change, 78, 1158-1163.

Porter, M. E. (1985). Competitive advantage: Creating \& sustaining superior performance. New York: The Free Press.

Pourshahid, A., Amyot, D., Peyton, L., Ghanavati, S., P. Chen, P., Weiss, M., \& Forster, A. J. (2009). Business process management with the user requirements notation. Electronic Commerce Research, 9(4), 269-316.

Ramaprasad, A., \& Williams, J. (1998). The utilization of critical success factors: A profile. Proceedings of the 29th Annual Meeting of the Decision Sciences Institute. LasVegas.

Raymond, L., Uwizeyemungu, S., \& Bergeron, F. (2006). Motivations to implement ERP in e-government: an analysis from success stories. Electronic Government, 3, 225-240.

Repa, V. (2006). Modeling business processes in public administration. In A.G. Nilsson, R. Gustas, W. Wojtkowski, G. Wojtkowski, S. Wrycza, J. Zupančič (Eds.), Advances in information systems development (pp. 107-118). Berlin: Springer. doi 10.1007/978-0-387-36402-5_10

Robey, D., Ross, J. W., \& Boudreau, M. C. (2007). Learning to implement enterprise systems: An exploratory study of the dialectics of change. Journal of Management Information Systems, 19(1), 17-46.

Rockart, J. \& Bullen, C., (1981). A primer on critical success factors. Center for Information Systems Research Working Paper No 69. Sloan School of Management, MIT, Cambridge, Massachusetts.

Rockart, J. F. (1979). Chief executives define their own data needs. Harvard Business Review, 57-81.

Rudden, J. (2007). Making the case for BPM: A benefits checklist. BPTrends 2007. Retrieved May 12, 2012 from http://www.bptrends.com/publicationfiles/01-07-ART-MakingtheCaseforBPMBenefitsChecklist-Rudden.pdf

Sambamurthy, V., \& Kirsch, L. J. (2000). An integrative framework of the information systems development process. Decision Science, 31(2), 391-411.

Sammon, D., \& Adam, F. (2010). Project preparedness and the emergence of implementation problems in ERP projects. Information \& Management, 47, 1-8.

Sarantis, D., Charalabidis, Y., \& Askounis D. (2011). A goal-driven management framework for electronic government transformation projects implementation. Government Information Quarterly, 28, 117-128.

Savvas, I., \& Bassiliades, N. (2009). A process-oriented ontology-based knowledge management system for facilitating operational procedures in public administration. Expert Systems with Applications, 36, 4467-4478.

Schäfermeyer, M., Rosenkranz, Ch., \& Holten, R. (2012). The impact of business process complexity on business process standardization. Business \& Information Systems Engineering, 4(5), 261-270. doi: 10.1007/s12599-012-0224-6

Schumm D., Leymann F., \& Streule A. (2010). Process views to support compliance management in business processes. Proceedings of E-Commerce and Web Technologies: 11th International Conference, EC-Web 2010, 131-142. Berlin: Springer.

Seltsikas, P. (2001). Organizing the information management process in process-based organizations. Proceedings of the 34th Hawaii International Conference on System Sciences (HICSS-34), vol. 8. Washington: IEEE Computer Society. 
Shah, S. I. H., Khan, A. Z., Bokhari, R. H., \& Raza, M. A. (2011). Exploring the impediments of successful ERP implementation: A case study in a public organization. International Journal of Business and Social Science, 2(22), 289-296.

Shang, S., \& Seddon, P. B. (2002). Assessing and managing the benefits of enterprise systems: The business manager's perspective. Information Systems Journal, 12(4), 271-299.

Škrinjar, R., Bosilj-Vukšic, V., \& Indihar-Štemberger, M. (2008) .The impact of business process orientation on financial and non-financial performance. Business Process Management Journal, 14(5), 738754.

Škrinjar, R., Štemberger, M. I., \& Hernaus, T. (2007). The impact of business process orientation on organizational performance. Proceedings of the Informing Science and IT Education Joint Conference, 171185. Santa Rosa: The Informing Science Institute. Retrieved October 12, 2012 from: http://proceedings.informingscience.org/InSITE2007/InSITE07p171-185Skri357.pdf

Smith, H., \& Fingar, P. (2003). Business process management: The third wave. USA: Meghan - Kiffe Press.

Somers, T. M., \& Nelson, K. (2001). The impact of critical success factors across the stage of ERP Implementation. Proceeding of the 34 Hawaii International Conference on System Sciences HICSS-34), vol. 8. Washington: IEEE Computer Society.

Specht, T., Drawehn, J., Thränert, M., \& Kühne, S. (2005). Modeling cooperative business processes and transformation to a service oriented architecture. Proceedings of E-Commerce Technology, Seventh IEEE International Conference, 249-256. Washington: IEEE Computer Society.

Subramanian, G. H., \& Peslak, A. R. (2012). ERP Implementation model, research findings, and its applications to government. In S. Chhabra \& M. Kumar (Eds.), Strategic enterprise resource planning models for e-government: Applications and methodologies (pp. 25-39). Hershey, PA: Information Science Reference. doi:10.4018/978-1-60960-863-7.ch002

Taylor, J. A., \& Williams, H. (1991). Public administration and the information polity. Public Administration, 69, 171-190.

Tregear, R., \& Jenkins, T. (2007). Government process management: A review of key differences between the public and private sectors and their influence on the achievement of public sector process management. BPTrends, October 2007. Retrieved September 15, 2012 from: http:/www.w.bptrends.com/publicationfiles/10-07-ART-Govt.ProcessMgt.Tregear\%20and\%20Jenkins-ph.pdf.

Trkman, P. (2010). The critical success factors of business process management. International Journal of Information Management, 30(2), 125-134.

Umble, E. J., Haft, R. R., \& Umble, M. M., (2003). Enterprise resource planning: Implementation procedures and critical success factors. European Journal of Operational Research, 146(2), 241-257.

Wang, E. T. G., Shih, S. P., Jiang, J. J., \& Klein, G. (2008). The consistency among facilitating factors and ERP implementation success: A holistic view of fit. The Journal of Systems and Software, 81, 16091621.

Weerakkody, V., Janssen, M., \& Dwivedi, Y. K. (2011). Transformational change and business process reengineering (BPR): Lessons from the British and Dutch public sector. Government Information Quarterly, 28(3), 320-328.

Weske M. (2007). Business process management: Concepts, languages, architectures. Berlin: Springer.

Westrup, Ch., \& Knight, F. (2000). Consultants and enterprise resource planning (ERP) Systems. Proceedings of the 8th European Conference on Information Systems ECIS(2000), Vienna. Retrieved September 15, 2012 from: http://is2.1se.ac.uk/asp/aspecis/20000198.pdf

Wieder, B., Booth, P., Matolcsy, Z. P., \& Ossimitz, M. L. (2006). The impact of ERP systems on firm and business process performance. Journal of Enterprise Information Management, 19(1), 13-29. 
Wilson, W. (1887). The study of administration. In J. M. Shafritz \& A. C. Hyde (Eds.), Classics of public administration (pp. 14-26). Orlando: Harcourt Brace College Publishers.

Winn, S., \& Oo, M T. (2011). Multi-agent model for automation of business process management system based on service oriented architecture. World Academy of Science. Engineering and Technology, 74, 670-675.

Young, R., Young, M., Jordan, E., \& O'Connor, P. (2012). Is strategy being implemented through projects? Contrary evidence from a leader in New Public Management. International Journal of Project Management, 30, 887-900.

Zaheer, A., Rehman, K., \& Khan, M. A. (2010). Development and testing of a business process orientation model to improve employee and organizational performance. African Journal of Business Management, 4(2), 149-161. Retrieved September 15, 2012 from: http://www.academicjournals.org/AJBM

Zairi, M. (1997). Business process management. Journal MCB University Press, 1, 64-80.

Ziemba, E., \& Papaj, T. (2012). E-government application at the regional level in Poland - The case of SEKAP. Proceedings of the Federated Conference on Computer Science and Information Systems, FedCSIS (2012), 1047-1054. Retrieved November 25, 2012 from: http://proceedings.fedesis.org/2012/pliks/80.pdf

Ziemba, E., \& Papaj, T. (2013). A Pragmatic Approach to the E-government Maturity in Poland - Implementation and Usage of SEKAP. Proceedings of 13th European Conference on eGovernment ECEG 2013, in print. Como: Academic Conferences and Publishing International Limited.

\section{Biographies}

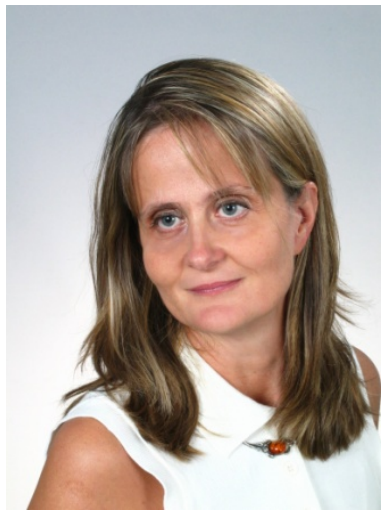

Ewa Ziemba is an associate Professor of Management Information Systems at the University of Economics in Katowice, Poland. Her research interests include information systems for knowledge management, e-business systems and information society. She has more than 150 refereed publications as books, journal papers and papers in conference proceedings. She has participated in several Polish and European research projects. Her current research project deals with designing a system approach to sustainable development of the information society. Her academic qualifications have been combined with practical experience - she has been working as the IT Project Manager for over ten years. Furthermore, she is a member of Polish Academy of Sciences (Poland), Informing Science Institute (USA), and International Association for Computer Information Systems (USA).

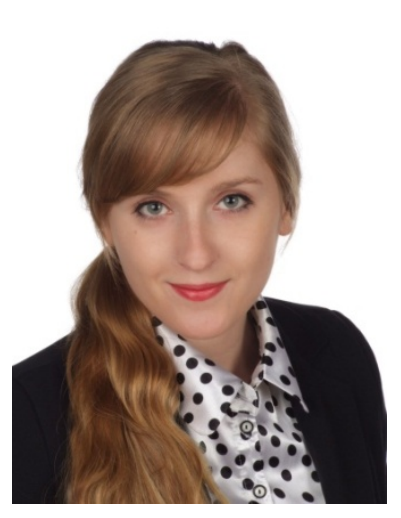

Iwona Obłąk is a business analysis specialist and IT project manager. Her principal research areas are focused on business process management, information systems in public administration (ERP, BI, BPM), business process modeling and business intelligence. 